NOTE

\title{
Lack of evidence of infectious salmon anemia virus in pollock Pollachius virens cohabitating with infected farmed Atlantic salmon Salmo salar
}

\author{
Carol A. McClure ${ }^{1}$, K. Larry Hammell ${ }^{1, *}$, Ian R. Dohoo ${ }^{1}$, Nellie Gagné ${ }^{2}$ \\ ${ }^{1}$ Department of Health Management, Atlantic Veterinary College, University of Prince Edward Island, \\ 550 University Avenue, Charlottetown, Prince Edward Island C1A 4P3, Canada \\ ${ }^{2}$ Department of Fisheries and Oceans, 343 University Avenue, Moncton, New Brunswick E1C 9X4, Canada
}

\begin{abstract}
The infectious salmon anemia (ISA) virus causes lethargy, anemia, hemorrhage of the internal organs, and death in farmed Atlantic salmon Salmo salar. It has been a cause of disease in Norwegian farmed Atlantic salmon since 1984 and has since been identified in Canada, Scotland, the United States, and the Faroe Islands. Wild fish have been proposed as a viral reservoir because they are capable of close contact with farmed salmon. Laboratory studies have shown that brown trout and sea trout Salmo trutta, rainbow trout Oncorhynchus mykiss, and herring Clupea harengus tested positive for the virus weeks after intra-peritoneal injection of the ISA virus. Pollock Pollachius virens are commonly found in and around salmon cages, and their close association with the salmon makes them an important potential viral reservoir to consider. The objective of this study was to determine the presence or prevalence of ISA virus in pollock cohabitating with ISA-infected farmed Atlantic salmon. Kidney tissue from 93 pollock that were living with ISA-infected salmon in sea cages were tested with reverse transcription-polymerase chain reaction (RT-PCR) test. Results yielded the expected $193 \mathrm{bp}$ product for positive controls, while no product was observed in any of the pollock samples, resulting in an ISA viral prevalence of $0 \%$. This study strengthens the evidence that pollock are unlikely to be an ISA virus reservoir for farmed Atlantic salmon.
\end{abstract}

KEY WORDS: Infectious salmon anemia $\cdot$ Pollock $\cdot$ Pollachius virens $\cdot$ Atlantic salmon $\cdot$ Prevalence Resale or republication not permitted without written consent of the publisher

\section{INTRODUCTION}

The infectious salmon anemia (ISA) virus causes a variety of problems in farmed Atlantic salmon Salmo salar including lethargy, anemia, hemorrhage of the internal organs, and death (Thorud \& Djupvik 1988, Byrne et al. 1998). It has been identified as a cause of disease in Norwegian farmed Atlantic salmon since 1984 (Thorud \& Djupvik 1988), and has since been identified in salmon farms in Canada (O'Halloran et al. 1999), Scotland (Rodger et al. 1998), the United States (Bouchard et al. 2001), Chile (Kibenge et al. 2001), and

*Corresponding author. Email: lhammell@upei.ca the Faroe Islands (Anonymous 2000). Despite aggressive control strategies, this disease continues to cause mortalities in Norwegian and Canadian salmon farms. One possible reason the disease continues is our inability to identify and remove the reservoir for the virus.

Wild fish have been proposed as a viral reservoir because they are capable of having close contact with the farmed salmon. Although wild Atlantic salmon were less susceptible to the ISA virus, they were still able to infect naïve salmon in cohabitational studies (Nylund et al. 1995a). Many laboratory studies have shown that other wild salmonid and non-salmonid fish including

(C) Inter-Research $2004 \cdot$ www.int-res.com 
brown trout and sea trout Salmo trutta (Nylund et al. 1995b, Devold et al. 2000), rainbow trout Oncorhynchus mykiss (Nylund et al. 1997, Snow et al. 2001), herring Clupea harengus (Nylund et al. 2002), and possibly even Arctic char Salvelinus alpinus (Snow et al. 2001) tested positive for the virus weeks after intraperitoneal injection. Brown trout and sea trout have been proposed as long-term carriers. Sea trout tested positive by reverse transcription polymerase chain reaction (RT-PCR) test for the virus at $135 \mathrm{~d}$ postinfection (Devold et al. 2000), and blood taken from a brown trout 7 mo post-infection, which was injected intraperitoneally into Atlantic salmon, was able to cause disease in the naïve salmon (Nylund et al. 1995b).

Pollock Pollachius virens are commonly found in and around salmon cages. Although pollock are not a salmonid, it is important to ensure this species is not a potential viral reservoir because of their close association with farmed Atlantic salmon. A recent laboratory study tested the ability of pollock to become infected with ISA virus and to transfer the virus to Atlantic salmon (Snow et al. 2002). The pollock were resistant to the virus, and the authors were unable to detect virus replication. Pollock that were infected by intraperitoneal injection were incapable of infecting naïve Atlantic salmon cohabitating in the same fish tank.

Laboratory studies are an excellent means to test hypotheses under controlled situations, but they cannot recreate the natural farming environment. The objective of this study was to identify the presence and, if present, the prevalence of ISA virus in pollock cohabitating with ISA-infected farmed Atlantic salmon.

\section{MATERIALS AND METHODS}

Pollock. Pollock that were living inside the salmon cages were collected either at the farm or at the processing plant when the salmon in the cages were being slaughtered due to an ordered depopulation for ISA infection. At harvest, the nets were lifted to one side of the cage to crowd the salmon such that it was possible to collect them with a dip net. If collected during the harvest, the pollock were separated from the salmon as they were removed from the cages and then brought to the laboratory, where tissues were sampled. If the pollock were collected at the abattoir, the pollock were removed from the large storage tubs that held the salmon and placed on ice until they were transported to the laboratory, where the tissues were sampled. Up to 21 pollock were sampled from each cage. All samples were collected between February 2000 and July 2001.

The cranial and caudal kidney tissues were sampled aseptically. The combined sample was placed into a $1.6 \mathrm{ml}$ microcentrifuge tube with the RNA preserva- tive, RNAlater ${ }^{\mathrm{TM}}$ (Ambion), for the RT-PCR test. Samples were transported on ice and then frozen at $-80^{\circ} \mathrm{C}$ within $24 \mathrm{~h}$ of collection.

RT-PCR testing for ISA virus. RNA was extracted with a solution of phenol and guanidine isothiocyanate (TRI reagent ${ }^{\circledR}$ ) according to the supplier's instructions. Random hexamers primed cDNA was synthesized using M-MuLV (RevertAid ${ }^{\mathrm{TM}}$ First Strand cDNA synthesis kit, MBI Fermentas) according to the supplier's instructions. PCR amplifications were performed in $20 \mu \mathrm{l}$ volumes containing $2 \mu \mathrm{l} \mathrm{cDNA}, 50 \mathrm{mM} \mathrm{KCl}, 30 \mathrm{mM}$ Tris$\mathrm{HCl} \mathrm{pH} \mathrm{8.4,} 2.5 \mathrm{mM} \mathrm{MgCl}_{2}, 0.01 \%$ Triton $^{\circledR}$ X100, $1 \mu \mathrm{l}$

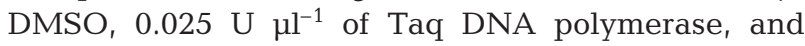
10 pmol of each primer. Primers used were S6-321F (5'ggacctgtacctgggagcat) and S6-513R (5'-agcaatgcagaccttgtagat). Cycling conditions were initial denaturation at $94^{\circ} \mathrm{C}$ for $2 \mathrm{~min}$ then 10 cycles of touchdown PCR $\left(94^{\circ} \mathrm{C}\right.$ for $30 \mathrm{~s}, 60^{\circ} \mathrm{C}$ dropping $1^{\circ} \mathrm{C}$ per cycle for $30 \mathrm{~s}$, and $72^{\circ} \mathrm{C}$ for $90 \mathrm{~s}$ ) and 35 more cycles at $94^{\circ} \mathrm{C}$ for $30 \mathrm{~s}, 50^{\circ} \mathrm{C}$ for $30 \mathrm{~s}$, and $72^{\circ} \mathrm{C}$ for $90 \mathrm{~s}$, followed by a final extension at $72^{\circ} \mathrm{C}$ for $5 \mathrm{~min}$ and holding at $20^{\circ} \mathrm{C}$. PCR products were electrophoresed on $1.5 \%$ agarose at $110 \mathrm{~V}$ and examined with ethidium bromide under UV light.

Statistics. The apparent prevalence was calculated as the number of positive pollock divided by the number of pollock tested. The exact $95 \%$ confidence interval for binomial count data was calculated using Stata7 software.

\section{RESULTS}

There were 93 pollock collected from 6 different sea cages from 5 different farms. The number of pollock sampled from each cage ranged from 7 to 21, with the average being 16 . All of the sea cages were being harvested because they were experiencing increased mortalities due to an outbreak of ISA. Results from the RT-PCR tests yielded the expected $193 \mathrm{bp}$ product for the positive controls, while no product was observed in any of the pollock samples, resulting in an apparent prevalence of the ISA virus of $0 \%$ and a $95 \%$ confidence interval $(0 \%, 3.9 \%$ [upper and lower limits]).

\section{DISCUSSION}

Isolated farms in New Brunswick have become diseased with ISA with no apparent link to other cases. In addition, certain bay areas in New Brunswick have become infected with ISA disease in every salmon grow-out cycle. For the last 6 yr, Limekiln Bay and Bliss Harbour have been dealing with repeated infections following complete depopulation of all farms and fallow periods of $6 \mathrm{wk}$ or more. The reason these farms become infected may be their proximity to a viral 
reservoir that continuously infects naïve fish. There has never been a definitive viral reservoir found, but 3 primary routes of re-infection are wild salmonids, wild non-salmonids, and invertebrates such as sea lice. Wild salmonids are relatively uncommon in the area of New Brunswick fish farms (Gilles Olivier pers. comm.) and therefore represent a less important source of infection. A wild non-salmonid fish that can transmit the virus but does not become clinically ill would be difficult to detect but important to control strategies limiting spread between sites.

The wild fish having the most contact with farmed Atlantic salmon in New Brunswick farms are pollock. The pollock are attracted to the salmon feed and stay in the vicinity of the cages in order to consume the feed that falls through the cage. If the pollock are small enough, they can enter the cage through the nets. If they stay in the cage for extended periods of time, their rapid growth may preclude them from exiting. Pollock may also enter the cages during net changes as new nets are pulled under the old nets incorporating the pollock near the cage into the population of salmon within the cage. In eastern Canada for the last 7 to $10 \mathrm{yr}$, there have been more pollock in the cages since the industry has moved to larger circular cages that capture many more pollock during net changes. When the farm managers and owners were asked about their perception of the number of pollock in their cages, $75 \%(59 / 79)$ answered that there were pollock in their salmon cages (C. A. McClure unpubl. data), indicating how frequently pollock are living in the farm cages.

Since these pollock were collected, Snow et al. (2002) showed that pollock are not likely candidates for being ISA viral carriers because pollock injected with the virus were able to eliminate the virus within $1 \mathrm{wk}$ in a laboratory study. Unlike a laboratory setting, farmed fish are exposed to many more stressors, including changes in weather, water temperature, oxygen content in the water, harmful algal blooms, sea lice, and concurrent diseases. Due to the close proximity of fish within sea cages, farmed salmon have increased contact between individuals, making viral transmission more likely once the virus has successfully infected at least 1 fish in a cage. Because fish are managed differently in the farming situation, it was important to know if the wild pollock living inside the farm cages are viral carriers.

Another reason for investigating pollocks' ability to become a carrier is that there are other fish from the Gadidae family, including Atlantic cod Gadus morhua and haddock Melanogrammus aeglefinus, that are in early commercial stages of production and may be raised in close proximity to salmon farms in Atlantic Canada. If pollock were capable of carrying the virus, other members of the Gadidae family may be carriers and deserve further evaluation. There is some experimental evidence that haddock may survive infection and replicate the virus (Mjaaland et al. 2002), but this has not been seen in wild fish surveys (Raynard et al. 2001). If these newly farmed species are capable of carrying the virus, then industry ISA control policies will need to incorporate surveillance and control to minimize the impact on salmon farms.

Although the results of this study indicated that the prevalence of ISA virus in wild pollock living in sea cages was zero, there are 2 assumptions that have been made. The ability of the RT-PCR test to identify a positive sample is the test's diagnostic sensitivity and must be fairly high so that there is confidence that the test did not falsely classify a positive pollock sample as negative. The sensitivity of this RT-PCR test that was used has been identified as moderately high at $85 \%$ for salmon (Dohoo et al. 2003) but has not been evaluated for use in pollock. Assuming the test performs the same for pollock as it does for salmon, there is an excellent chance $(85 \%)$ that the test result would have found a single positive pollock if there was one in the samples tested.

Another assumption was that pollock kidney would be the organ with the highest level of virus if the pollock was infected. A distribution study has been performed in Atlantic salmon to identify the organs that were RTPCR positive after cohabitating with infected Atlantic salmon (Mikalsen et al. 2001). Atlantic salmon gill, liver, and spleen were also positive at differing times, but the heart was most consistently positive from 5 to $70 \mathrm{~d}$ cohabitation with ISA-infected salmon. If there was an infected pollock, performing the RT-PCR on combined heart, gills, liver, spleen, and kidney from the pollock may have increased the chance of identifying it as positive. However, the sampling of multiple tissues was beyond the scope of this initial evaluation of pollock.

Limiting the number of pollock in a salmon cage is recommended as they are carriers of other pathogens such as sea lice (Lyndon \& Toovey 2001). The presence of pollock may also act as a stressor because of the increase in total stocking density and an unfamiliar species being introduced into the cage.

The result of this study strengthens the evidence found by Snow et al. (2002) that pollock are unlikely to be a viral reservoir for farmed Atlantic salmon. However, other wild fish commonly found in New Brunswick farm cages like cod, lumpfish Cyclopterus lumpus, and Atlantic mackerel Scomber scombrus should be investigated to assess whether they can be viral reservoirs. Because herring swim freely in and out of the salmon cages and haddock may be farmed near salmon cages, the likelihood of these fish infecting farmed Atlantic salmon should be evaluated as there is some evidence that they are carriers of the ISA virus. 
Acknowledgements. We thank the New Brunswick Atlantic salmon farmers and the managers of the abattoirs for participating in this study. We also thank the veterinary students who helped collect the samples. We are grateful for funding assistance from the Natural Science and Engineering Research Council and the Atlantic Veterinary College for this study.

\section{LITERATURE CITED}

Anonymous (2000) Infectious salmon anaemia in the Faroe Islands. Dis Info Office Int Epizooties 13:53-59

Bouchard DA, Brockway K, Giray C, Keleher W, Merrill PL (2001) First report of infectious salmon anemia (ISA) in the United States. Bull Eur Assoc Fish Pathol 21:86-88

Byrne PJ, MacPhee DD, Ostland VE, Johnson G, Ferguson HW (1998) Haemorrhagic kidney syndrome of Atlantic salmon, Salmo salar L. J Fish Dis 21:81-91

Devold M, Krossoy B, Aspehaug V, Nylund A (2000) Use of RT-PCR for diagnosis of infectious salmon anaemia virus (ISAV) in carrier sea trout Salmo trutta after experimental infection. Dis Aquat Org 40:9-18

Dohoo IR, Nerette P, Hammell KL, McClure CA (2003) Evaluating diagnostic tests for ISA. In: Proceedings of the New Brunswick ISA research workshop, March 31, 2003, St. Andrews, NB. Department of Agriculture, Fisheries, and Aquaculture, St. George, NB

Kibenge FS, Garate ON, Johnson G, Arriagada R, Kibenge MJ, Wadowska D (2001) Isolation and identification of infectious salmon anaemia virus (ISAV) from Coho salmon in Chile. Dis Aquat Org 45:9-18

Lyndon AR, Toovey JPG (2001) Occurrence of gravid salmon lice (Lepeophtheirus salmonis (Kroeyer)) on saithe (Pollachius virens (L.)) from salmon farm cages. Bull Eur Assoc Fish Pathol 211:84-85

Mikalsen AB, Teig A, Helleman AL, Mjaaland S, Rimstad E (2001) Detection of infectious salmon anaemia virus (ISAV) by RT-PCR after cohabitant exposure in Atlantic salmon Salmo salar. Dis Aquat Org 47:175-181

Editorial responsibility: Chris Baldock, Brisbane, Australia
Mjaaland S, Rimstad E, Cunningham CO (2002) Molecular diagnosis of infectious salmon anaemia. In: Cunningham $\mathrm{CO}$ (ed) Molecular diagnosis of salmonid diseases. Kluwer Academic Publishers, London, p 1-22

Nylund A, Kvenseth AM, Krossoy B (1995a) Susceptibility of wild salmon (Salmo salar L.) to infectious salmon anaemia (ISA). Bull Eur Assoc Fish Pathol 15:152-156

Nylund A, Alexandersen S, Rolland JB, Jakobsen P (1995b) Infectious salmon anemia virus (ISAV) in brown trout. J Aquat Anim Health 7:236-240

Nylund A, Kvenseth AM, Krossoy B, Hodneland K (1997) Replication of the infectious salmon anaemia virus (ISAV) in rainbow trout, Oncorhynchus mykiss (Walbaum). J Fish Dis 20:275-279

Nylund A, Devold M, Mullins J, Plarre H (2002) Herring (Clupea harengus): a host for infectious salmon anemia virus (ISAV). Bull Eur Assoc Fish Pathol 22:311-318

O'Halloran JLF, L'Aventure JP, Groman DB, Reid AM (1999) Infectious salmon anemia in Atlantic salmon. Can Vet J 40: 351-352

Raynard RS, Murray AG, Gregory A (2001) Infectious salmon anaemia virus in wild fish from Scotland. Dis Aquat Org 46:93-100

Rodger HD, Turnbull T, Muir F, Millar S, Richards RH (1998) Infectious salmon anaemia (ISA) in the United Kingdom. Bull Eur Assoc Fish Pathol 18:115-116

Snow M, Raynard RS, Bruno DW (2001) Comparative susceptibility of Arctic char (Salvelinus alpinus), rainbow trout (Oncorhynchus mykiss) and brown trout (Salmo trutta) to the Scottish isolate of infectious salmon anaemia virus. Aquaculture 1966:47-54

Snow M, Raynard R, Bruno DW, Van Nieuwstadt AP, Olesen NJ, Loevold T, Wallace C (2002) Investigation into the susceptibility of saithe Pollachius virens to infectious salmon anaemia virus (ISAV) and their potential role as a vector for viral transmission. Dis Aquat Org 50 500:13-18

Thorud K, Djupvik HO (1988) Infectious anaemia in Atlantic salmon (Salmo salar L.). Bull Eur Assoc Fish Pathol 8: 109-111

Submitted: May 29, 2003; Accepted: July 9, 2004 Proofs received from author(s): September 28, 2004 